\title{
The genotype of Entamoeba histolytica in bloody diarrhea samples of humans, cows and sheep
}

\author{
H.H. Naser \\ Zoonotic Diseases Research Unit, College of Veterinary Medicine, University of Al-Qadisiyah, Al-Qadisiyah, Iraq \\ Email: hassan.naser@qu.edu.iq
}

(Received September 25, 2019; Accepted January 20, 2019; Available online August 11, 2020)

\begin{abstract}
The present study was carried out to detect the genotype of E. histolytica that found in human fecal specimens and animals feces with Haemorrgic diarrhea by amplifying the SREHP gene, using RT-PCR technique, Cyber green dye and by fusion curve analysis. The study also included molecular detection of amoebic parasite species using Nested-PCR technology. The study recorded presence of parasites $E$. histolytica; $E$. dispar; E. bovis with total infection rates 82.9, 26.8, 4.9\%, respectively. The study revealed the presence of E. histolytica parasite in five different genotypes (I, II, III, IV, V) with rate presence 9.75 , $53.65,19.5,9.75,7.3 \%$, respectively. In conclusion, there are five genotype of $E$. histolytica, in human and animals, most of these genotypes may be infect any host, E. bovis was recorded in sheep and cows.
\end{abstract}

Keywords: Entamoeba spp., Real-Time PCR, SREHP, Genotyping, Melting curve analysis

DOI: $10.33899 /$ ijvs.2020.126135.1242, C2020, College of Veterinary Medicine, University of Mosul.

This is an open access article under the CC BY 4.0 license (http://creativecommons.org/licenses/by/4.0/).

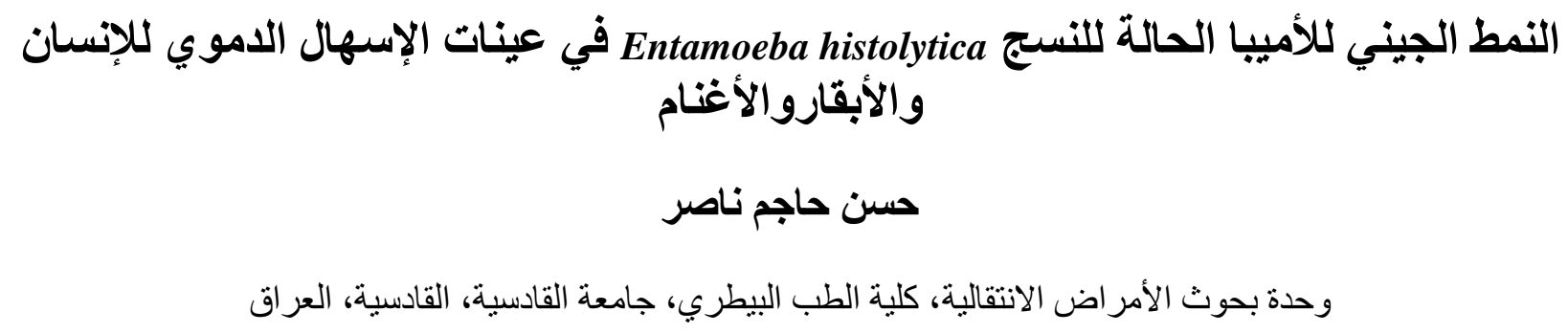

صمدت الدراسة لتحديد النمط الجيني لطفيلي الاميبيا الحالة للنسيج E.hitolytica الموجودة في عينات الاسهال الدموي للإنسان

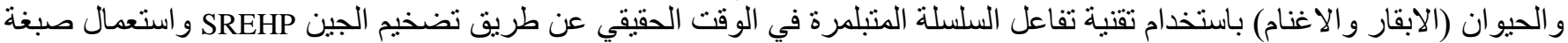

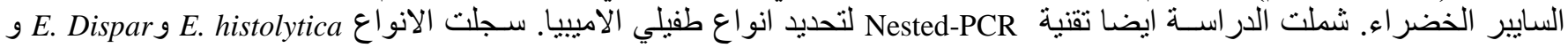

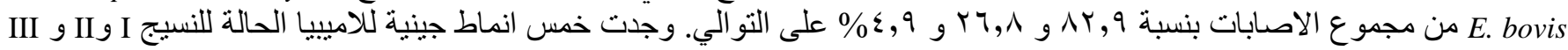

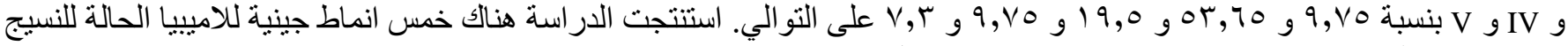
في الانسان و الحيو ان معظمها قد تصيب اي مضيف، تسجيل و

\section{Introduction}

Many species of amoeba genus were identified in the first quarter of the twentieth century (1) and are spread in various regions of the world in the developing countries of the Indian subcontinent, Central and South America, and in the tropics of Africa (2), as well as many species that parasitize many hosts, some of which are common to more than one host (3).

The parasite has the ability to devour red blood cells by Erythrophagocytosis through the process of analyzing its plasma membrane and then digesting the base material, as 
the ability of the feeding phases to digest erythrocyte may be due to the mechanism of adhesion to the surfaces of the cells and inhibit the adhesion of the parasite decreases phagocytosis and digestion of the erythrocytes during the parasite invasion of the large intestine layers (4), attributed (5) to (Hemoglobinase) and for the need of iron for the survival of the parasite, hence, the digestion of blood hemoglobin to get iron $(4,5)$. The ability of $(E$. dispar) to cause liver injury, and some studies taken from the comparison of the genetic structure of both species (dispar and histolytica) have concluded that some sites of the gene responsible for the encoding of certain proteins of pathogenicity in the E. histolytica are the same in the E. dispar such genes as the amoebic hole Gal / GalNacinhibitable lectin. $(6,7)$.

In the presence of E. histolytica and E. bovis as single infection indicating that these parasites can shift from a coexistence with the host to pathogenicity (5), many studies have returned (and until recently) that have attempted to differentiate between $E$. histolytica infection and its cause, from invasions of tissues into and out of the intestine and between the infectious of $E$. dispar and other parasites, even those studies were considered unsatisfactory (8). This hypothesis is offset by recent studies that, using experimental animals, have demonstrated the events of the parasite E. dispar for focal ulcers and have an analytical capacity of the epithelial layer (9). performance development of a parasite which isolated from a person with no symptoms of amoebiasis in a medium containing intestinal flora, it was observed endemicity of amoebiasis taking into account the overlap between the two parasites and pathogenic bacteria or intestinal flora, which may alter the behavior of these organisms into a nurse, since some pathogenic bacteria have genes that directly or indirectly encoded molecules activated by the inflammatory response (10).

Table 1: Nested PCR primers

\section{Materials and methods}

\section{Samples collection}

A 34 human samples from Al-Hamza General Hospital and twenty eight animals samples were collected from different areas of Al-Hamza district, the presence of the parasite was confirmed in all samples by general stool examination via microscopic examination in the laboratories of the parasitology and microbiology branch in the College of Veterinary Medicine - Al-Qadisiyah University.

\section{Stool DNA extraction}

DNA was extracted from fecal samples using the Genomic DNA stool (AccuPrep® Stool DNA Extraction Kit) supplied by Bioneer Korean company according to the manufacturer instructions. This kit was designed to quickly and conveniently extract of DNA from genomic DNA from microorganisms in stool samples. In the presence of chaotropic salt, DNA is bound to glass fibers fixed in a column. Proteins and other contaminants are removed through washing stems, and the DNA isolated and eluted in the final elution step.

\section{Nested PCR method}

Nested PCR assay was performed detection $E$. histolytica and E. dispar according to (11), and E. bovis according to (12), the Nested PCR method was including using primary PCR primers for detection Entamoeba sp. Followed by Nested PCR primers that used for detection of E. histolytica, E. dispar, and E. bovis (Table 1).

The first round of Nested PCR master mix that include Entamoeba sp. Primary primers were prepared by using (AccuPower® PCR PreMix Kit, Bioneer, Korea) (Table 2).

\begin{tabular}{llcc}
\hline Primer & & Sequences (5'-3') & Product size \\
\hline \multirow{2}{*}{ Entamoeba sp. } & $\mathrm{F}$ & TTTGTATTAGTACAAA & $\sim 900 \mathrm{bp}$ \\
& $\mathrm{R}$ & GTAAGTATTGATATACT & \\
E. histolytica & $\mathrm{F}$ & AATGGCCCATTCATTCAATG & $550 \mathrm{bp}$ \\
& $\mathrm{R}$ & TTTAGAAACAATGCTTCTCT & \\
E. dispar & $\mathrm{F}$ & GAGGATCCATGTTCGCATTTTTATTGT & $729 \mathrm{bp}$ \\
& $\mathrm{R}$ & GAGGATCCTTAGAAGACAATTGCCA & \\
E. bovis & $\mathrm{F}$ & AAACTGCGGACGGCTCATTA & $174 \mathrm{bp}$ \\
\hline
\end{tabular}

After that, these PCR master mix components that mentioned in table above placed in standard PCR PreMix Kit that containing all other components which needed to PCR reaction such as (Taq DNA polymerase, dNTPs, Tris-
$\mathrm{HCl} \mathrm{pH}$ : 9.0, $\mathrm{KCl}, \mathrm{MgCl}_{2}$, stabilizer, and tracking dye). Then, all the PCR tubes transferred into Exispin vortex centrifuge at 3000rpm for 3 minutes. The reaction was performed in PCR thermocycler (T100 thermal cycler 
BioRad. USA) by set up the following thermocycler conditions; Reactions were performed using the following protocol, initial denaturation at $95^{\circ} \mathrm{C}$ for $4 \mathrm{~min}$, and 35 cycles at $95^{\circ} \mathrm{C}$ for $1 \mathrm{~min}, 47^{\circ} \mathrm{C}$ for $1 \mathrm{~min}$ and $72^{\circ} \mathrm{C}$ for 2 min, and a final incubation at $72^{\circ} \mathrm{C}$ for $7 \mathrm{~min}$.

The second round Nested PCR master mix that include E. histolytica, E. dispar, and E. bovis primers were prepared by using (AccuPower® PCR PreMix Kit, Bioneer, Korea) (Table 3).

Table 2: PCR master mix

\begin{tabular}{lc}
\hline First round PCR master mix & Volume \\
\hline DNA template 5-50ng/ $\mu \mathrm{L}$ & $5 \mu \mathrm{L}$ \\
Entamoeba sp. Primary forward primer & $1 \mu \mathrm{L}$ \\
Entamoeba sp. primary reverse primer & $1 \mu \mathrm{L}$ \\
PCR water & $13 \mu \mathrm{L}$ \\
\hline Total volume & $20 \mu \mathrm{L}$ \\
\hline
\end{tabular}

Table 3: Nested PCR master mix

\begin{tabular}{lc}
\hline Nested PCR master mix & Volume \\
\hline First round PCR product & $2 \mu \mathrm{L}$ \\
Second round E. histolytica, or E. dispar, and & $1 \mu \mathrm{L}$ \\
or E. bovis Forward primer (10pmol) & \\
Second round E. histolytica, or E. dispar, and & $1 \mu \mathrm{L}$ \\
or E. bovis Reverse primer (10pmol) & $16 \mu \mathrm{L}$ \\
PCR water & $20 \mu \mathrm{L}$ \\
Total volume & \\
\hline
\end{tabular}

After that, these Nested PCR master mix component that mentioned in table above placed in same PCR PreMix
Kit Then, all the PCR tubes transferred into Exispin vortex centrifuge at 3000rpm for 3 minutes.

The reaction was performed in PCR thermocycler (T100 thermal cycler BioRad. USA) by set up the following thermocycler conditions; Reactions were performed using the following Nested PCR protocol, initial denaturation at $95^{\circ} \mathrm{C}$ for $4 \mathrm{~min}$, and 35 cycles at $95^{\circ} \mathrm{C}$ for $1 \mathrm{~min},\left(50^{\circ} \mathrm{C}\right.$ for E. histolytica, $60^{\circ} \mathrm{C}$ for E. dispar, $57^{\circ} \mathrm{C}$ for E. bovis) for 1 min and $72^{\circ} \mathrm{C}$ for $1 \mathrm{~min}$, and a final incubation at $72^{\circ} \mathrm{C}$ for 1 $\min$.

After that PCR products were examined by electrophoresis in a $1 \%$ agarose gel, stained with ethidium bromide, and visualized under UV Transilluminator.

\section{Real-Time PCR method}

Real-Time PCR was performed genotyping of $E$. histolytica based on allelic discrimination during melting curve of SREHP gene in positive E. histolytica according to (13) the method was firstly included PCR reaction for amplification of SREHP gene based on SREHP primer (Table 4).

The Real-Time PCR amplification reaction was done by using (AccuPower ${ }^{\circledR}$ Green Star ${ }^{\mathrm{TM}}$ qPCR PreMix kit, Bioneer. Korea) and the qPCR master mix were prepared for each sample according to company instruction (Table $5)$.

After that, these RT PCR master mix components that mentioned in table above was transferred into Green star qPCR premix standard plate tubes that contain the SYBER green dye and other PCR amplification components.

Then the plate mixed by Exispin vortex centrifuge for 3 minutes, then placed in MiniOpticon Real-Time PCR system and applied the following thermocycler conditions (Table 6).

Table 4: PCR and RT-PCR primers (SREHP) for E. histolytica as (12)

\begin{tabular}{lccc}
\hline Primer & & Sequences $\left(5^{\prime}-3^{\prime}\right)$ & Product size \\
\hline \multirow{2}{*}{ PCR-SREHP } & $\mathrm{F}$ & GCTAGTCCTGAAAAGCTTGAAGAAGCTG & 549bp \\
& $\mathrm{R}$ & GGACTTGATGCAGCATCAAGGT & \\
RT PCR-SREHP & $\mathrm{F}$ & TATTATTATCGTTATCTGAACTACTTCCTG & \multirow{2}{*}{$450 \mathrm{bp}$} \\
\hline
\end{tabular}

Table 5: RT PCR master mix

\begin{tabular}{ll}
\hline RT PCR master mix & Volume \\
\hline SREHP gene PCR product & $2 \mu \mathrm{L}$ \\
RT PCR-SREHP gene forward primer & $1 \mu \mathrm{L}$ \\
RT PCR-SREHP gene Reverse primer & $1 \mu \mathrm{L}$ \\
PCR water & $16 \mu \mathrm{L}$ \\
Total volume & $20 \mu \mathrm{L}$ \\
\hline
\end{tabular}

Table 6: RT PCR master mix

\begin{tabular}{lccc}
\hline qPCR step & Temperature & Time & Cycle \\
\hline Initial & $95^{\circ} \mathrm{C}$ & $3 \mathrm{~min}$ & 1 \\
$\begin{array}{l}\text { Denaturation } \\
\begin{array}{l}\text { Denaturation } \\
\text { Annealing }\end{array}\end{array}$ & $95^{\circ} \mathrm{C}$ & $10 \mathrm{sec}$ & \\
$\begin{array}{l}\text { Extension } \\
\begin{array}{l}\text { Detection } \\
\text { Melting }\end{array}\end{array}$ & $55^{\circ} \mathrm{C}$ & $30 \mathrm{sec}$ & 45 \\
\hline
\end{tabular}




\section{Statistical analysis}

The data were analyzed statistically to obtain the percentage and extract the Chi-square value $\left(\chi^{2}\right)$.

\section{Results}

The study recorded a total infection rate $66.1 \%$ where 41 samples showed a positive result by microscopic examination (Table 7). Percentage of infection was detected by using Nested PCR.

Table 7: Percentage of total infection using Nested PCR

\begin{tabular}{lcccc}
\hline \multirow{2}{*}{ Samples } & \multicolumn{2}{c}{ Positive samples } & \multicolumn{2}{c}{ Negative sample } \\
\cline { 2 - 5 } & No. & Percent $\%$ & No. & Percent $\%$ \\
\hline Human & 24 & 38.7 & 10 & 16.1 \\
Cows & 9 & 14.5 & 5 & 8 \\
Sheep & 8 & 12.9 & 6 & 9.7 \\
\hline Total & 41 & 66.1 & 21 & 22.8 \\
\hline
\end{tabular}

The study recorded the percentage of total infection with E. histolytica amounted to 79.1; 100; 75 (Figure 1) and E. dispar by $33.3 ; 22.2 ; 12.5$ (Figure 2) in human, cows and sheep feces respectively, and E. bovis by $0 ; 11.1 ; 12.5$ (Figure 3) in cattle and sheep, respectively (Table 8).

Table 8: Percentage of total infection by Nested PCR

\begin{tabular}{lcccc}
\hline Samples & & E. histolytica & E. dispar & E. bovis \\
\hline Human & $\mathrm{n}$ & 19 & 8 & 0 \\
$(24)$ & $\%$ & 79.1 & 33.3 & 0 \\
Cows & $\mathrm{n}$ & 9 & 2 & 1 \\
(9) & $\%$ & 100 & 22.2 & 11.1 \\
Sheep & $\mathrm{n}$ & 6 & 1 & 1 \\
$(8)$ & $\%$ & 75 & 12.5 & 12.5 \\
\hline Total & $\mathrm{n}$ & 34 & 11 & 2 \\
$(41)$ & $\%$ & 82.9 & 26.8 & 4.9 \\
\hline
\end{tabular}

The study showed the presence of the three parasites in the animals' samples, while the human samples were free from the presence of the parasite E. bovis (Table 8). The study showed significant effect of parasite type in the occurrence of infection with erythrocytes $(\mathrm{F}=4.46)$, significant difference in the incidence between $E$. histolytica and E. bovis only where the animal type did not show significant effect $(\mathrm{F}=0.848)$ at significant level $\mathrm{P} \geq$ 0.05 .

\section{Genotypes of $\boldsymbol{E}$. histolytica results}

Genotyping of E. histolytica based on the Melting curve analysis that to detect the by Real-Time PCR assay based on amplification of SREHP gene by SYBER green dDNA binding dye which can differentiate melting temperatures
(Tm) for each genotype 41. The Real-Time PCR Melting analysis results showed the presence of 5 different melting temperatures $79,81,82,83,84^{\circ} \mathrm{C}$ of the SREHP gene for parasites (Figure 4). Each one melting temperature face one genotype 5 genotypes of $E$. histolytica were distributed as follows I, II, III, IV, V which corresponds to the melting temperatures $79,81,82,83,84^{\circ} \mathrm{C}$ respectively, where genotypes were present $9.75,53.65,19.5,9.75$ and 7.3, respectively (Figure 5) (Table 9).

Table 9: Genotypes of E. histolytica based on melting temperature Tm

\begin{tabular}{ccccc}
\hline Total & Melting Tm. & Genotype & No. & $\%$ \\
\hline \multirow{4}{*}{41} & 84 & I & 4 & 9.75 \\
& 83 & II & 22 & 53.65 \\
& 82 & III & 8 & 19.5 \\
& 81 & IV & 4 & 9.75 \\
& 79 & V & 3 & 7.3 \\
\hline
\end{tabular}

The relationship between the genotypes of $E$. histolytica and the presence of erythrocytes

The results showed that the presence of genotypes recorded in this study and found in fecal samples containing red blood cells was the following, where genotype II was more (22 out of 41). Genotype V was the least present in the total samples as it was found in only three samples, which was not found in cattle and sheep samples, whereas the study recorded the appearance of the five genotypes in human fecal samples (Table 10).

Table 10: Distribution of genotypes among hosts

\begin{tabular}{llccccc}
\hline \multirow{2}{*}{ Genotype } & \multicolumn{2}{c}{ Human } & \multicolumn{2}{c}{ Cows } & \multicolumn{2}{c}{ Sheep } \\
\cline { 2 - 7 } & No. & $\%$ & No. & $\%$ & No. & $\%$ \\
\hline I & 3 & 7.3 & 1 & 2.4 & 0 & 0 \\
II & 13 & 31.7 & 3 & 7.3 & 6 & 14.6 \\
III & 3 & 7.3 & 4 & 9.75 & 1 & 2.4 \\
IV & 2 & 4.8 & 1 & 2.4 & 1 & 2.4 \\
V & 3 & 7.3 & 0 & 0 & 0 & 0 \\
\hline Total & 24 & & 9 & & 8 & \\
\hline
\end{tabular}

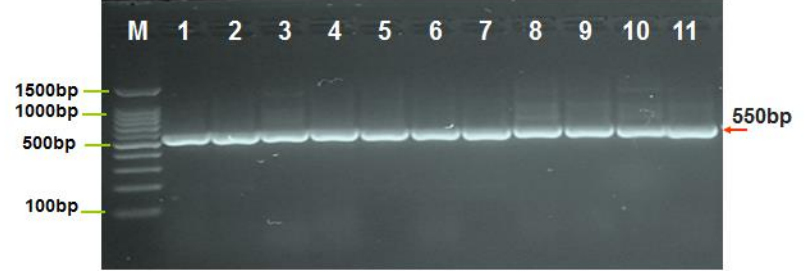

Figure 1: Electrophoresis in the agarose gel of products (550bp) PCR of rRNA for E. histolytica. 


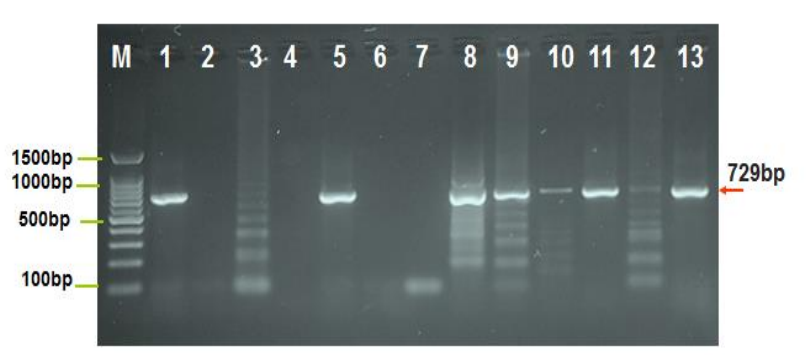

Figure 2: Electrophoresis in the agarose gel of products(729bp) PCR of rRNA for $E$. dispar.

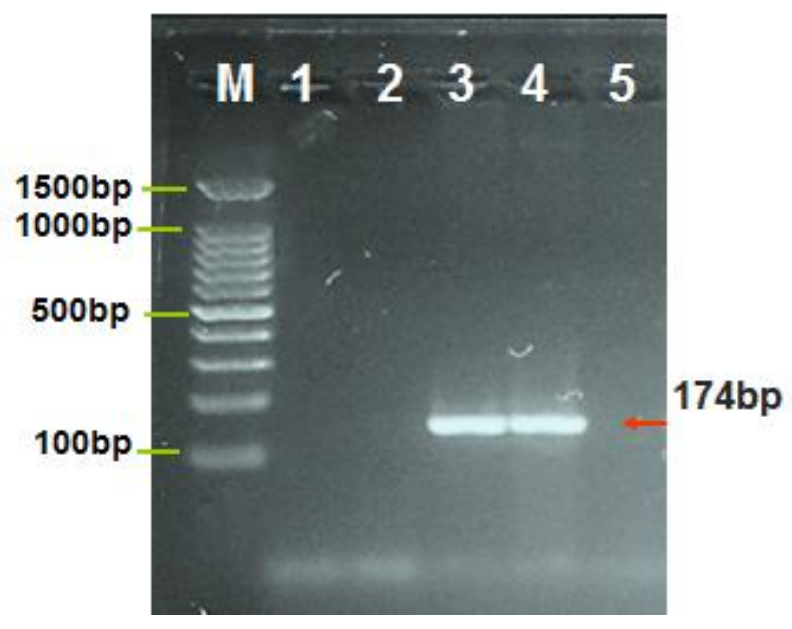

Figure 3: Electrophoresis in the agarose gel of products (174bp) PCR of rRNA for E. bovis.

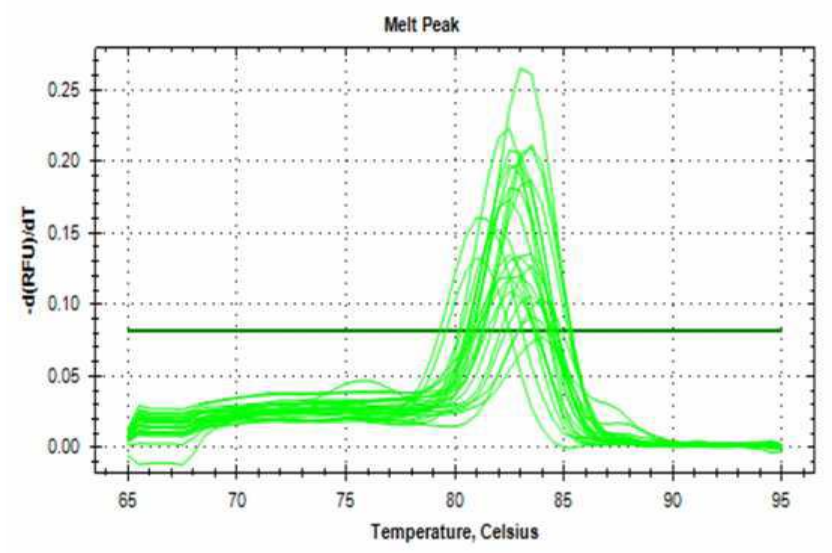

Figure 4: Different types of melting temperature peak for SREHP gene in E. histolytica

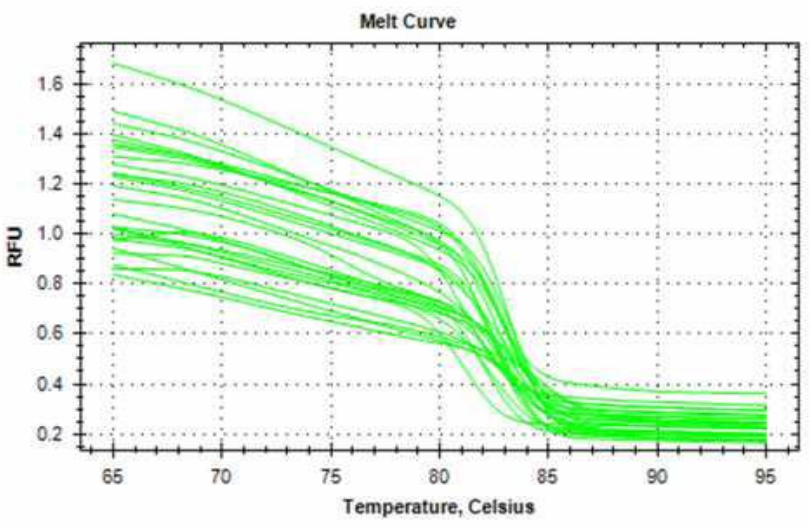

Figure 5: Melting curve for SREHP gene

\section{Discussion}

The study recorded the presence of E. histolytica and $E$. dispar in Humans, cows and sheep samples, indicating the possibility of transmission of these parasites between humans and animals (14) However, the incidence of infection with amoeba parasites in these animals or their functioning as potential reservoirs remains unclear. It is known that these parasites are transmitted through contaminated food and water where unhealthy habits, culture and use of contaminated water are considered. Irrigating crops, watering animals or using human and animal waste in agriculture help spread and transmission of the parasite among different hosts (15).

The presence of E. bovis in the host (cows) and in other hosts other than the usual (sheep), where previous studies confirmed the possibility of the presence and isolation of the parasite from other ruminants non-cattle such as deer and sheep may be due to the use of contaminated water for watering animals or the use of the same areas for grazing, which facilitates the transmission of parasites between them (16).

The results showed the high incidence of E. histolytica, which confirms the high ability of the parasite to analyze and devour the cells of tissues and red blood cells inside and outside the intestines (17) because they have enzymes analyzing the intestinal mucosa (8). The presence of $E$. dispar in humans may indicate a high pathogenicity of the parasite taking into account the presence of mixed infection with tissue-amoeba and the presence of a single infection of the parasite. The presence of other pathogens or auxiliary to the symptoms of infestation (15).

The presence of the parasite E. bovis even if only a small percentage confirms the ability of the parasite to cause infection even if the presence of another pathogen as a common infection. 
The appearance of different genotypes reflecting the different melting temperatures of SREHP gene amplification products showed the large diversity in the nucleotide sequences and the content of the gene, reflecting a wide phenotypic variation of the genotype (II). Reflects the high ability of this genotype to spread and move among different hosts, especially with its presence in all hosts, Unlike Genotype V, which has the lowest ratio among all hosts (18).

The study showed the presence of four genotypes in human and cows feces in varying proportions, which the possibility of this genotype and its ability to be transmitted between humans and cows, genotype (V) which didn't appear in sheep samples, may mean that these genotypes cannot infect sheep during the period of collection time of samples.

The study showed the presence of genotype $\mathrm{V}$ with the lowest presence rate, which means that the ferocity of this genotype is low and its ability to infect is lower than the other genotypes. In cows as a host of the parasite.

The broad spectrum of genotypes that have emerged during the study and the appearance of some genotypes with the presence of erythrocytes in fecal samples may indicate the virulence of these genotypes and their ability to invade tissues and cause disease, but do not reveal the role of other pathogens. In the intestine, parasite virulence was observed to be proportional to ambient conditions outside the intestine, which may indicate significant variations in the parasite metabolism directly or indirectly.

\section{Conclusion}

There are five genotypes of E. histolytica, in human and animals, most of these genotypes may infect any host, $E$. bovis was recorded in sheep and cows.

\section{Acknowledgements}

The authors are grateful to Members Zoonotic Diseases Research Unit, College of Veterinary Medicine for part sponsorship of this study.

\section{Conflict of interests}

The Parasitology Department College of Veterinary Medicine for development and evaluation of Diagnostic tools.

\section{Reference}

1. Lark CG, Kaffashian F, Tawari B, Windsor J, Flesner T, Davies M, Mina CG, Blessmann J, Ebert F, Peschel B, Van J, An L, Colin J, Macfarlane L, Egbert T. New insights into the phylogeny of Entamoeba species provided by analysis of four new small subunit
rRNA genes. Inter J Syst Evol Microbiol. 2006;56(9):2235-2239. DOI: 10.1099/ijs.0.64208-0

2. Bhattacharya, S, Bhattacharya A. Amoebiasis and Entamoeba species: unexplored liaisons. Trop Gastroenterol. 2013;34(2):55-57. DOI: $10.7869 / \operatorname{tg} .2012 .98$

3. Das K, Ganguly S. Evolutionary genomics and population structure of Entamoeba histolytica. Comp Struct Biotechnol J. 2014;12(14):26-33. doi.org/10.1016/j.csbj.2014.10.001

4. Okada M, Huston CD, Mann BJ, Petri WA, Kita K, Nozaki T. Proteomic analysis of phagocytosis in the enteric protozoan parasite Entamoeba histolytica. Eu Cell. 2005;4(4):827-831. DOI: 10.1128/EC.4.4.827-831.2005

5. Dolabella SS, Serrano LJ, Navarro GF, Cerritos R. Amoebic liver abscess production by Entamoeba dispar. Anna Hepatol. 2012;11(1):107-117. DOI: 10.1016/S1665-2681(19)31494-2

6. Ximénez C, Morán P, Rojas L, Valadez A, Gómez A, Ramiro M, Cerritos R, González E, Hernández E, Oswaldo P. Novelties on Amebiasis: neglected tropical disease. J Global Infect Dis. 2011;3(2):166-74. doi: 10.4103/0974-777X.81695

7. Ali IK, Mondal U, Roy S, Haque R, Petri WA. Evidence for a link between parasite genotype and outcome of infection with Entamoeba histolytica. J Clin Microbiol. 2007;1(45) 285-289. doi: 10.1128/JCM.01335-06

8. Blessmann J, Buss H, Ton N, Phuong A, Dinh BT, Viet N, Quynh T, An Le V, Mohamed D, Abd A, Terry F, Jackson J, Ravdin I, Egbert T. Real Time PCR for detection and differentiation of Entamoeba histolytica and Entamoeba dispar in fecal samples. J Clin Microbiol. 2003;40(12):4413-4417. doi: 10.1128/JCM.40.12.4413-4417.2002

9. Costa AO, Gomes MA, Rocha OA, Silva EF. Pathogenicity of Entamoeba dispar under xenic and monoxenic cultivation compared to a virulent E. histolytica. Revista Instituto Med Trop Sao Paulo. 2006;48(5):245-250. doi.org/10.1590/S0036-46652006000500002

10. Galva MM, Domı MC, Franco E, Meza I. The interplay between Entamoeba and enteropathogenic bacteria modulates epithelial cell damage. PLOS Negl Trop Dis. 2008;2(7):266. doi.org/10.1371/journal.pntd.0000266

11. Haque R, Huston CD, Hughes M, Houpt E, William A, Petri Jr. Amebiasis. N Engl J Med. 2003;34(8):1565-73. DOI: $10.1056 / \mathrm{NEJMra022710}$

12. Rahman SM, Haque R, Roy S, Mondal MH. Genotyping of Entamoeba histolytica by real-time polymerase chain reaction with sybr green I and melting curve analysis. Bangl J Vet Med. 2006;4(1):53-60. doi.org/10.3329/bjvm.v4i1.1526

13. Yee LL, Lau YL, Anthony C, Fakhrurrazi SA, Ibrahim J, Ithoi I, Mahmud R. Real-time PCR assay in differentiating Entamoeba histolytica, Entamoeba dispar, and Entamoeba moshkovskii infections in Orang Asli settlements in Malaysia. Parasit Vectors. 2013;6(1):250. doi: 10.1186/1756-3305-6-250

14. Pham DP, Nguyen VH, Hattendorf J, Zinsstag J, Dac CP, Peter OP. Risk factors for Entamoeba histolytica infection in an agricultural community in Hanam province, Vietnam. Parasit Vect. 2011;4(1):102. DOI: 10.1186/1756-3305-4-102

15. Levecke B, Dreesen L, Dorny P, Verweij JJ, Vercammen F, Casaert S, Vercruysse J, Geldhof P. Molecular identification of Entamoeba spp. in Captive Nonhuman Primates. J Clin Microbiol. 2010;48(8):29882990. DOI: 10.1128/JCM.00013-10

16. Stensvold CR, Lebbad M, Clark CG. Genetic characterization of uninucleated cyst-producing Entamoeba spp. from ruminants. Inter J. Parasitol. 2010;40(7):775-778. doi.org/10.1016/j.ijpara.2010.03.003

17. Sateriale A, Huston CD. A sequential model of host cell killing and phagocytosis by Entamoeba histolytica. J Parasitol Res. 2011:11551165. doi.org/10.1155/2011/926706

18. Dinoop KP, Parija SC, Mandal J, Swaminathan RP, Narayanan P. Comparison of nested-multiplex, Taqman and SYBR Green real-time PCR in diagnosis of amoebic liver abscess in a tertiary health care institute in India. Indian J Med Res. 2016;143(1):49-56. doi: 10.4103/0971-5916.178592 